\title{
Evaluation of Five Essential Oils by Gas Chromatography-Mass Spectrometry and their Effect on Fungal Growth Inhibition and Sensory Acceptability of Soymilk
}

\author{
Marguerite Niyibituronsa ${ }^{1,2,3}$, Arnold Nola Onyango ${ }^{2}$, Svetlana Gaidashova ${ }^{1}$, Samuel Imathiu ${ }^{2}$, Zhang Ming $^{3}$, \\ Yang Ruinan ${ }^{3}$, Zhang Weiqi ${ }^{3}$, Wang XiuPin ${ }^{3}$, Zhang Qi $^{3}$, Zhang Zhaowei ${ }^{3} \&$ Li Peiwu $^{3}$ \\ ${ }^{1}$ Rwanda Agriculture Board, Rwanda \\ ${ }^{2}$ Jomo Kenyatta University of Agriculture and Technology, Nairobi, Kenya \\ ${ }^{3}$ Oil Crops Research Institute of the Chinese Academy of Agriculture Science, Wuhan, China \\ Correspondence: Marguerite Niyibituronsa, Rwanda Agriculture Board, Rwanda, P.O.BOX 5016 Kigali, Rwanda. \\ Tel: 250-788-848-200. E-mail: niyibituronsam@gmail.com
}

Received: December 29, 2019

Accepted: February 15, $2020 \quad$ Online Published: March 17, 2020

doi:10.5539/jfr.v9n2p36

URL: https://doi.org/10.5539/jfr.v9n2p36

\begin{abstract}
Essential oils are widely used in the food industry as natural food preservatives to extend product shelf life and as flavoring agents. However, not much has been done on their use in soymilk. The aim of the study is to determine the compounds of five essential oils by GC-MS and their effect on fungal growth inhibition and sensory acceptability of soymilk. The components of the essential oils of five spices, namely citronella, basil, cinnamon, eucalyptus and mint were analysed by gas chromatography-mass spectrometry (GC-MS). The minimum inhibitory concentration (MIC) of the essential oils was tested on the fungus Aspergillus flavus 3.4408 on PDA (agar dilution method). Sensory evaluation of soymilk flavored with the essential oils of citronella, basil and mint at different concentrations was done by ten member panelists using a 9-point hedonic scale. The main compound for basil was eugenol $83.26 \%$. Cinnamon contained cinnamaldehyde (97.3\%). The main compounds in citronella (Cymbopogon nardus) were limonene (38.51\%), citronellal (30.29\%). Eucalyptus (Eucalyptus globulus) essential oil mainly contained eucalyptol/cineole (76.70\%), and Mint (Mentha arvensis): Menthol $42.72 \%$, Menthone $25.72 \%$. The MICs of citronella, basil, cinnamon, eucalyptus and mint were $5-10 \mu \mathrm{l} / \mathrm{ml}, 0.5-1$ $\mu \mathrm{l} / \mathrm{ml}, \leq 0.1 \mu \mathrm{l} / \mathrm{ml},>>10 \mu \mathrm{l} / \mathrm{ml}$ and 10-20 $\mu \mathrm{l} / \mathrm{ml}$, respectively. Thus, cinnamon was the most effective in inhibiting fungal growth, while eucalyptus was the least effective. These essential oils improved the soymilk flavor. Mint was the most preferred flavor, followed by citronella and basil. Thus, essential oils especially mint and citronella can be used for improving acceptability of soymilk at low concentration.
\end{abstract}

Keywords: basil, CFU, citronella, cinnamon, eucalyptus, mint, sensory attributes, soybean

\section{Introduction}

Soybean contains oil with polyunsaturated fatty linoleic and linolenic acids and the oxidation of those fatty acids during processing is associated with the beany flavors responsible for reduced consumer acceptability of soybean milk (Davles, 1987). Apart from attempts at reduction of off flavours from soymilk during extraction, other options have been undertaken to remove the beany odor (Kinney, 2003; Hideo, 1979). For example, Davles (1987) carried a study to remove the off flavor by reducing lipoxygenase genetically to improve soybean products acceptability. Orange juice, pineapple and banana have also been used to improve the taste of soybean milk (Kale et al., 2012; Laswai et al., 2009). However, not much has been done on the use of essential oils for improving soybean flavor.

Essential oils are active botanical constituents derived from plant materials such as leaves (lemon grass, ocimum, mint), leaves and stems (geranium, patchouli, cinnamon), flowers (rose, mimosa, lavender), seeds (fennel, coriander, nutmeg), fruits (orange, lemon, bergamot), rhizomes (ginger, curcuma, orris), gums (storax, myrrh, balsam of Peru), bark (cinnamon, cassia, canella), roots (vetiver, valerian, angelica) and wood (cedar, sandal, pine) (Handa et al., 2008). Different methods are used to extract essential oils, namely, water steam distillation, Solvent Extraction, $\mathrm{CO}_{2}$ Extraction, Maceration, Effleurage, Cold Press Extraction, and water and steam distillation. The last is the most favored for oil quality and higher yield (Handa et al., 2008). The boiling point of 
essential oils, a mixture of monoterpenes, sesquiterpenes and their oxygenated products, ranges from $150^{\circ} \mathrm{C}$ to $300^{\circ} \mathrm{C}$ higher than the boiling point of water $100^{\circ} \mathrm{C}$ but by heating and moisture from the steam the pressure increase in the plant material and the oils volatilize from the plant (Tandon, 2008). For better yield and quality of the essential oils the temperature should be maintained as low as possible and plant material packed well in the distillation still (Koul et al., 2004). Fresh oils do not have color but with time oxidation may occur, leading to dark color. Thus, they need to be stored in a cool, dry place in a dark glass container and close tightly (Rassem et al., 2016). The essential oils (EOs) are used in wide variety of food industry as food preservative (Hyldegaard et al., 2012). They have antibacterial and antifungal properties and are increasingly used as an alternative of synthetic products (Nazaro et al., 2017). The composition of essential oils of any species varies according to genotypes and environmental factors. For example, three different chemotypes were reported for the essential oil of Ocimum ciliatum accessions in Iran (Moghaddam et al., 2017). Therefore, in utilizing essential oils for improving the flavor of soymilk, it is necessary to characterize the chemical composition of the essential oils to allow for product standardization.

Basil essential oils are used to flavor foods (Ozcan and Chalchat, 2011). For flavoring recipes, 1-3 drops of basil essential oil is better than the use of fresh or dried basil (Sustainable Baby Steps, 2019). Mint can also be used as flavoring agent in food (Fatih et al., 2017). Essential oils from Cymbopogon (Citronella and Lemon grass), an aromatic tropical plant in the family of Poaceae, which gives flavor to recipes including tea, can potentially be used for improving soymilk flavor. Essential oil of Cymbopogon has been obtained by water steam distillation (Millet, 2015, Ranitha et al., 2014). Cymbopogon is relatively cheap and available (Laswai et al., 2009). However, these sources of essential oils have not been tested for quantity of extract to be used in soybean milk.

\section{Materials and Methods}

\subsection{Essential Oils Compounds Analysis by GC-MS}

Soybeans and essential oils (Cymbopogon nardus, Ocimum basilicum, Cinnamomum verum, Eucalyptus globulus and Mentha) were purchased at Hengcheng natural perfume oil co., Ltd, JiangXi province, China. Analysis of EOs compounds by Gas Chromatography- Mass Spectrometer (GC-MS) was done using GC-MS Agilent at OCRI; Mass spectra were obtained on Agilent 5973 MSD mass spectrometer, coupled directly to 7890A gas chromatograph fitted with a J \& W DB-5ms, $0.25 \mathrm{~mm}$ i.d. x $30 \mathrm{~m}, 0.25$ micron coating thickness, fused silica capillary column. The GC/MSD was operated under the following conditions: injector temperature $-240^{\circ} \mathrm{C}$; transfer line $-300^{\circ} \mathrm{C}$; the column temperature was initially held at $50^{\circ} \mathrm{C}$ for $3 \mathrm{~min}$, increased to $240^{\circ} \mathrm{C}$ at a rate of $3^{\circ} \mathrm{C} / \mathrm{min}$, and then held at this higher temperature for $2 \mathrm{~min}$; injection - $0.1 \mu \mathrm{l}(10 \% \mathrm{soln}$.), split 1:20, and helium with a flow rate of $1.2 \mathrm{ml} / \mathrm{min}$ was used as the carrier gas; Electron energy of $70 \mathrm{eV}$ in the electron ionization mode, and an ion source temperature of $200^{\circ} \mathrm{C}$. Scan Range $41-415,1$ scan/ sec., Solvent delay $2.00 \mathrm{~min}$ (Adams, 2017). A comparison of retention time of compounds with the standards was done. In addition, a comparison of mass spectra of the components with the mass spectra stored in the National Institute of Standards and Technology (NIST) reference library was done, and the calculation of percentages of compounds in the EOs.

\subsection{Test of EOs Minimum Inhibitory Concentration on Fungal Growth}

Strains of fungi species Aspergillus flavus 3.4408 was obtained from the culture collection of Oil Crops Research Institute of the Chinese Academy of Agricultural Science, Department of Mycotoxins Research, Wuhan in China. The fungi were cultured in petri dishes on Potato dextrose agar (PDA) for 7 days at $28^{\circ} \mathrm{C}$. Extraction of the spores was done by washing the colonies in petri dishes with Tween $800.1 \% \mathrm{v} / \mathrm{v}$ distilled water. Using a pipette tip, the extract/spores suspension was collected in a tube (Moosavi-Nasab et al., 2018). The suspension was tested for contamination by adding $0.5 \mathrm{ml}$ in $50 \mathrm{ml}$ of Liquid Sabourand Medium and incubating at $28^{\circ} \mathrm{C}$ in an incubator shaker for 2 days. If not contaminated hyphens growth was visible in small ball in the medium. The spore concentration was determined using a hemocytometer slide by an optical microscope (Nikon eclipse E100, Japan) and the Aspergillus flavus spore suspension was diluted in $0.1 \%$ Tween 80 to bring the final inoculum to $5.10^{5} \mathrm{CFU} / \mathrm{ml}$ (CLSI, 2012).

The EOs and Medium PDA were prepared using agar dilution method (Hammer et al., 1999; Davari and Ezazi, 2017). The concentrations of $1,3,5,10,20,50$ and $100 \mu 1 / 10 \mathrm{~mL}$ of PDA were used. Inoculation was done with $10 \mu \mathrm{l}$ of fungal suspension in triplicate and sample control. Petri dishes were sealed and incubated at $28^{\circ} \mathrm{C}$. The growth was observed on 2 days basis and each fungal colony was measured in two perpendicular directions, and the colony mean diameter was obtained after 7 days. The minimum inhibition concentration (MIC) was determined using the formula: Inhibition $\%=(\mathrm{C}-\mathrm{T} / \mathrm{C}) * 100$; Where C: Diameter of fungal colony in control plates and T: Diameter of fungal colony in treated plates (Davari and Ezazi, 2017; Li et al., 2016). 


\subsection{Sensory Evaluation of Soymilk Flavored with EOs}

Different levels of flavor one drop, 2 drops and 3 drops were added in $1 \mathrm{~L}$ of soymilk except the control. The method of soymilk preparation that preserves nutrient was used (Hosken, 1999; Niyibituronsa et al., 2019; Nyagaya, 2008). A taste panel of ten members determined the acceptability of different soymilk flavored with Basil, Cymbopogon and Mint by using a 9-point hedonic scale from like extremely $=9$ to dislike extremely $=1$ (Hashmi, 2007). The products were evaluated for the taste, color, appearance, odor using an evaluation form (Appendix 1).

\subsection{Data Analysis}

Data was analyzed using SPSS 22.0 and MS Excel. Analysis of variance (ANOVA) was conducted and significance of differences between samples was declared significant at $P<0.05$ probability levels.

\section{Results and Discussion}

\subsection{Analysis of Essential Oils Compounds by GC-MS}

The five essential oils were analysed for compounds by GC-MS. Figure 1 shows the compounds in Basil (Ocimum basilicum) essential oil. The main compounds for Basil were eugenol (83.26\% at 22.06 Retention time (RT)) and Caryophyllene (10.36\% at 23.98 RT).

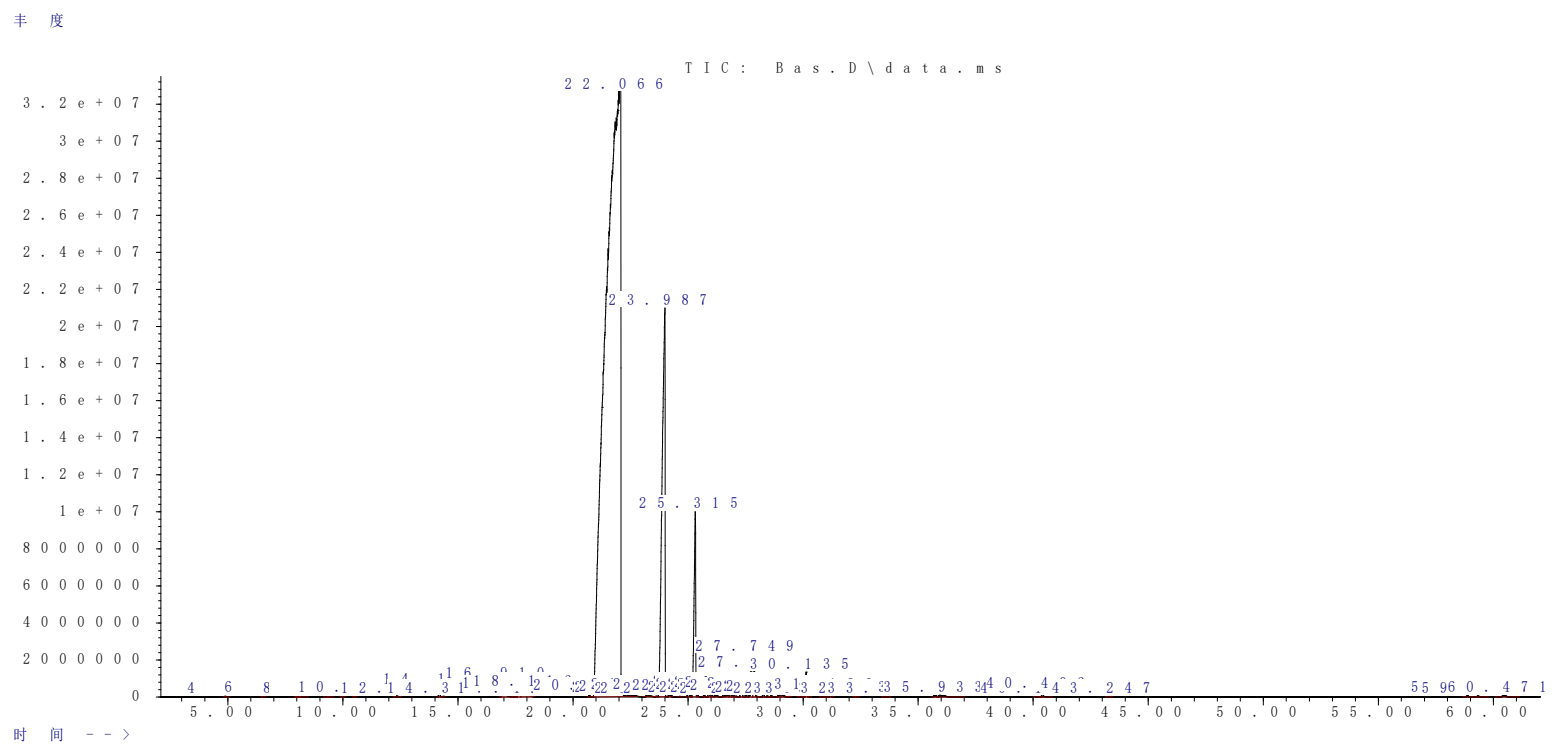

Figure 1. Basil essential oil compounds

Ocimum genus counts over 150 species. Depending on the species, growth stage, season and the geographic area where the plants are found, the compounds vary (Chamorro et al., 2012; Poonkodi, 2016). Some have eugenol as major compound up to $87 \%$, especially for species of eugenol chemotype, similar to our findings (Koutsos et al., 2009; Muráriková et al., 2017). Others have linalool and chavicol as major compounds (Chamorro et al., 2012; Muráriková et al., 2017; Poonkodi, 2016). According to De Martino study, the main constituents of basil oil were iso-pinocamphone (35.10\%) and carvone (39.70\%), while eugenol was in trace, only 1\% (De Martino et al., 2009).

The compounds for Cinnamon (Cinnamomum verum) are shown in Figure 2. The main compound is Cinnamaldehyde (97.26\% at $18.99 \mathrm{RT}$ ). 


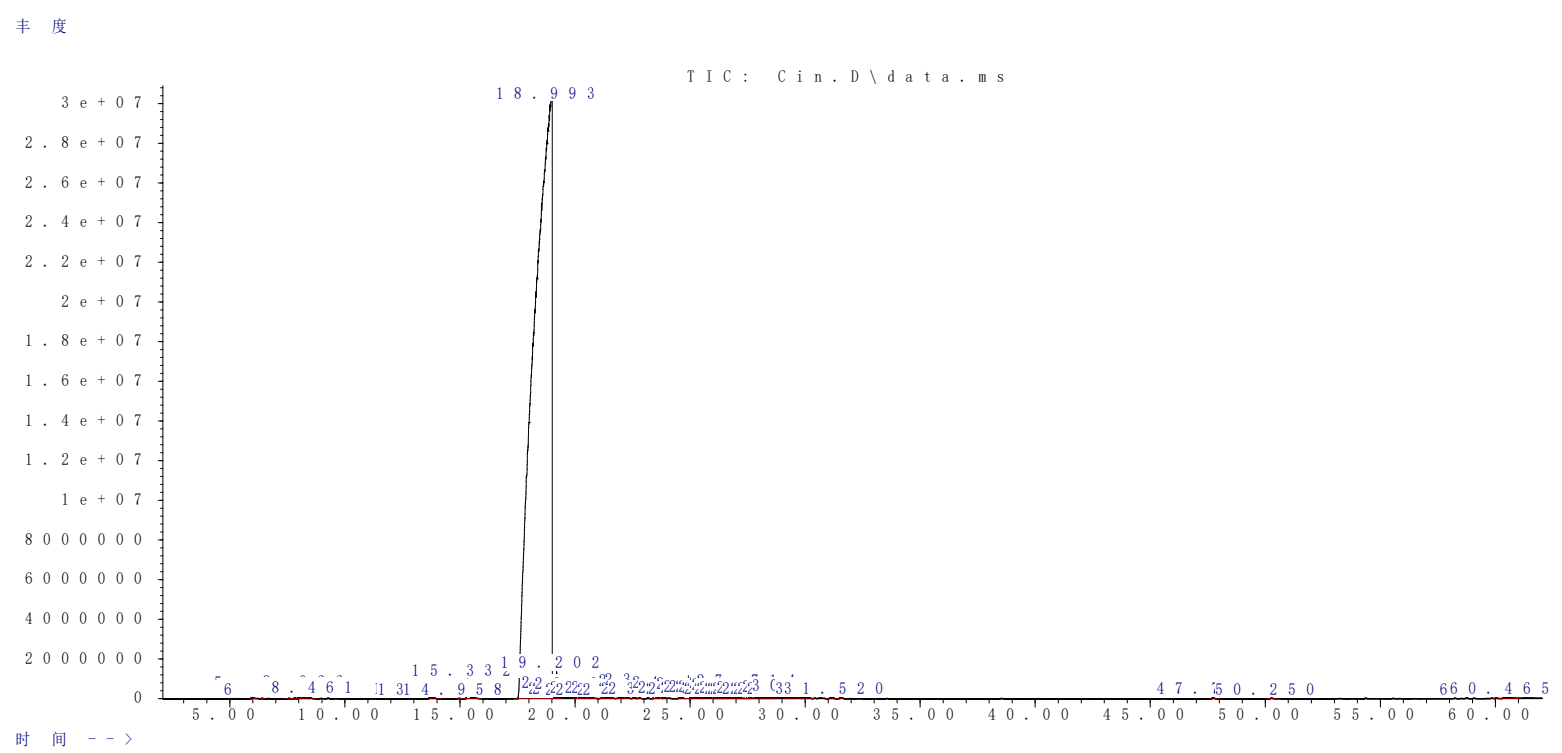

Figure 2. Cinnamon essential oil compounds

The composition depends on the growth stage and the segment of the plant (Vangalapati et al., 2012). Cinnamon leaves essential oil contains cinnamaldehyde 1.00 to $5.00 \%$ and eugenol: 70.00 to $95.00 \%$ while the bark contain cinnamaldehyde 65.00 to $80.00 \%$ and eugenol 5.00 to $10.00 \%$ (Jayaprakasha et al., 2002; Rao and Gan, 2014).

The compounds in Citronella (Cymbopogon nardus) are given in Figure 3 and the main compounds are Limonene (38.51\% at $8.23 \mathrm{RT})$, Citronellal $(30.29 \%$ at $8.17 \mathrm{RT})$, Citronillol (14.32\% at $12.84 \mathrm{RT})$, Geraniol/citral (7.9\% at 14.61 RT), and Cuparene (9\% at 17.02 RT).

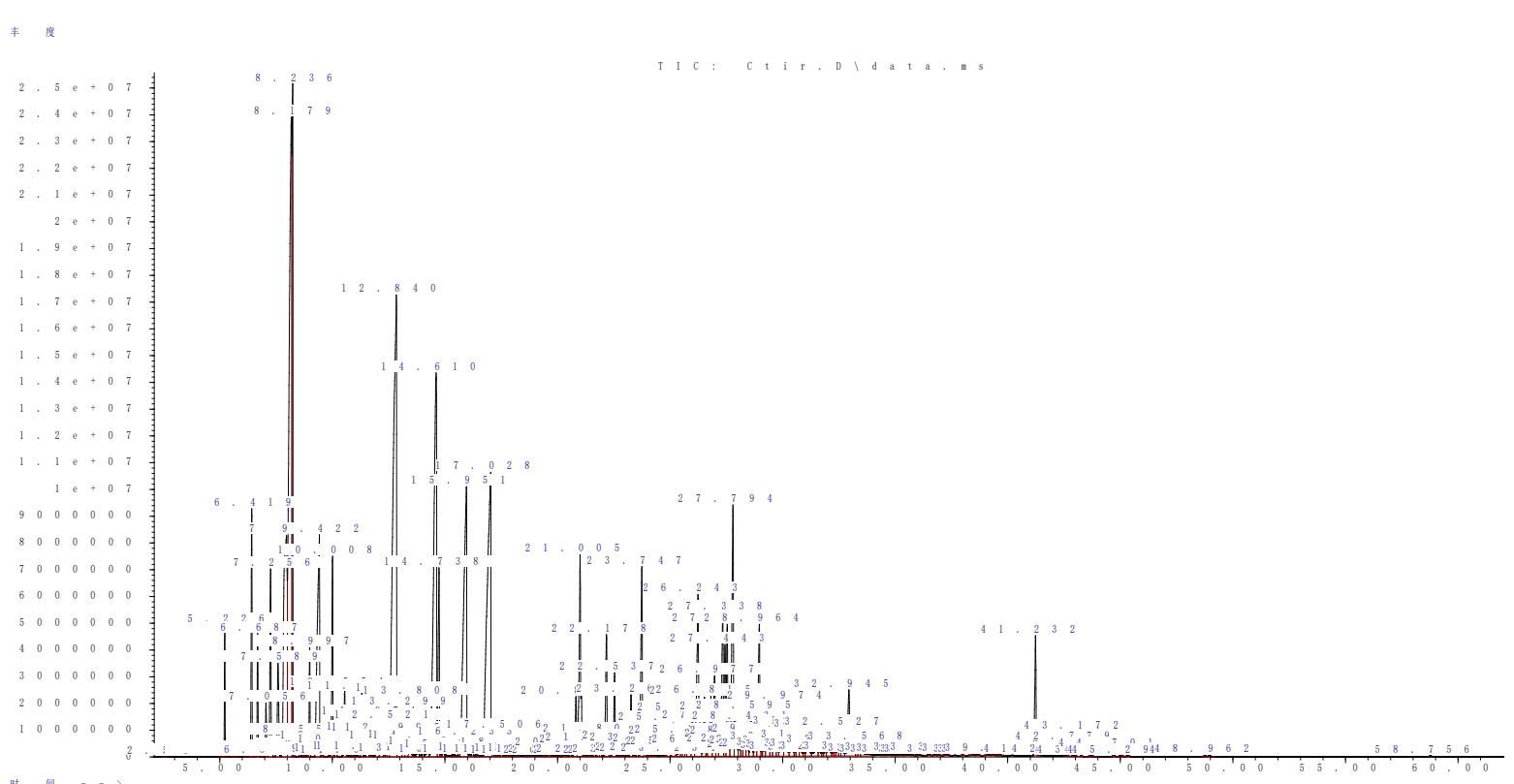

Figure 3. Citronella essential oil compounds

Another study reported Citronellal (33.8\%), geraniol (21.6\%), citronellol (9.2\%)(Regnault-Roger, 1997). Compounds differ from one species of Cymbopogon to another; C. martini has Geraniol (64.0\%-92.6\%), C. Flexuosus Citral (80.6\%-84.4\%), C. pendulus (Lemongrass) Citral (75.9\%), limonene (5.5\%), C. winterianus of Kashmir Citronellal (31.1-35.4\%), Geraniol (22.4-30.2\%), Citronellol (7.4- 11.0\%) while C. Winterianus of Himalayan region of India contain Geraniol (50.1\%), Citral (21.8\%), Citronellal (11.8\%) (Wany et al., 2013). 
Figure 4 shows compounds in Eucalyptus (Eucalyptus globulus) and the main compounds are Eucayptol/Cineole $(76.70 \%$ at $8.48 \mathrm{RT})$, Carene $(9.70 \%$ at $7.61 \mathrm{RT})$, Terpinene $(4.16 \%$ at $6.71 \mathrm{RT})$ and Phellandrene $(3 \%$ at 7.26 RT).

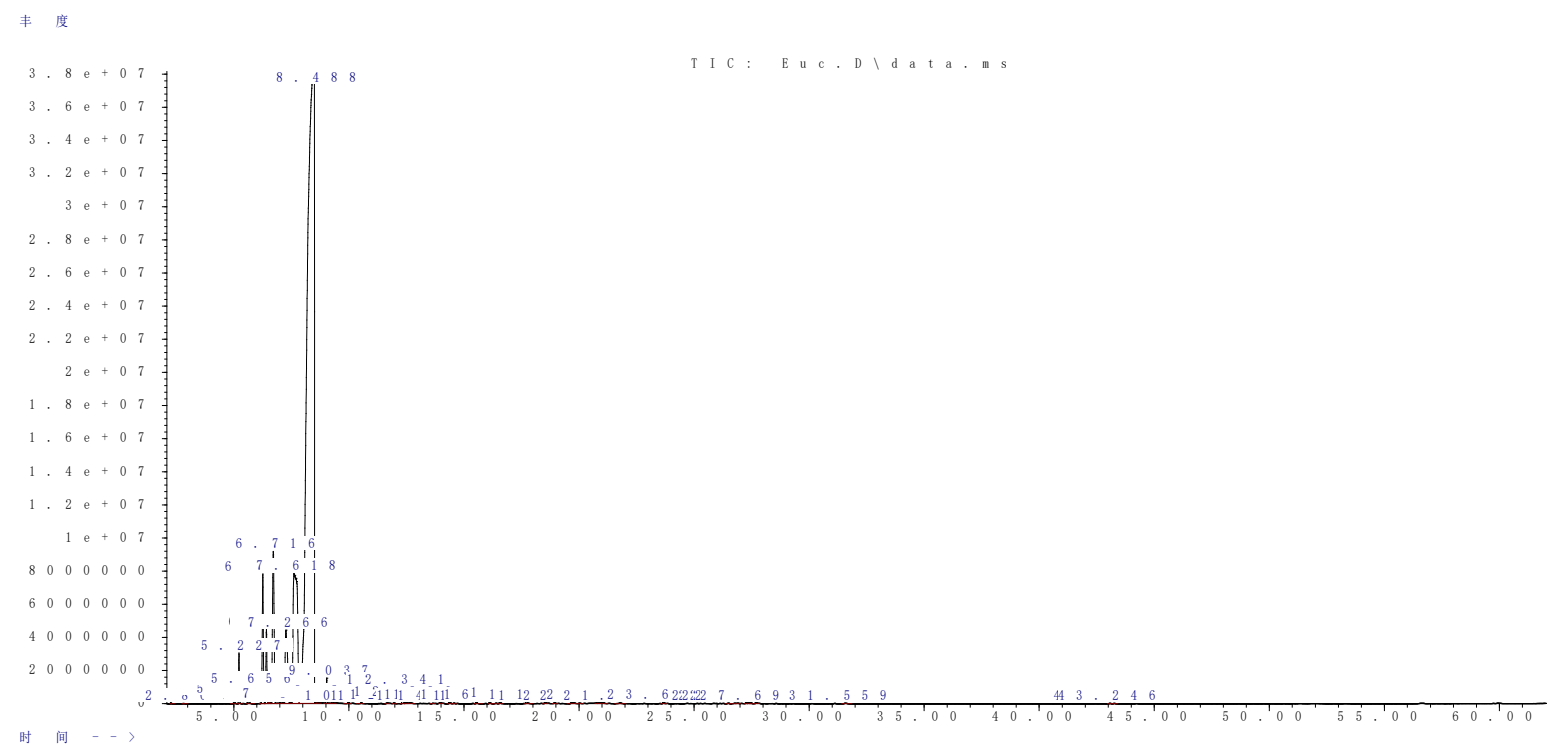

Figure 4. Eucalyptus essential oil compounds

Previous study reported cineole content of eucalyptus essential oil as $86 \%$, pinene $3.9 \%$ and cymene $2.4 \%$ (Regnault-Roger, 1997). Some study found $44.08 \%$ of Cineole, $1.51 \%$ of Terpinene and many traces of compounds (Davari and Ezazi, 2017). Chemical compounds may vary within the same species due to the development stage of the plant used to extract the essential oils or the plant adaptation to the environment (Chamorro et al., 2012).

In mint (mentha) essential oil, the compounds are shown in Figure 5 and the main compounds were Menthol (42.72\% at 14.25 RT), Menthone (25.72\% at 13.04 RT), Limonene (4.92\% at 8.05 RT) and Pinene $(3.18 \%$ at 5.25 RT).

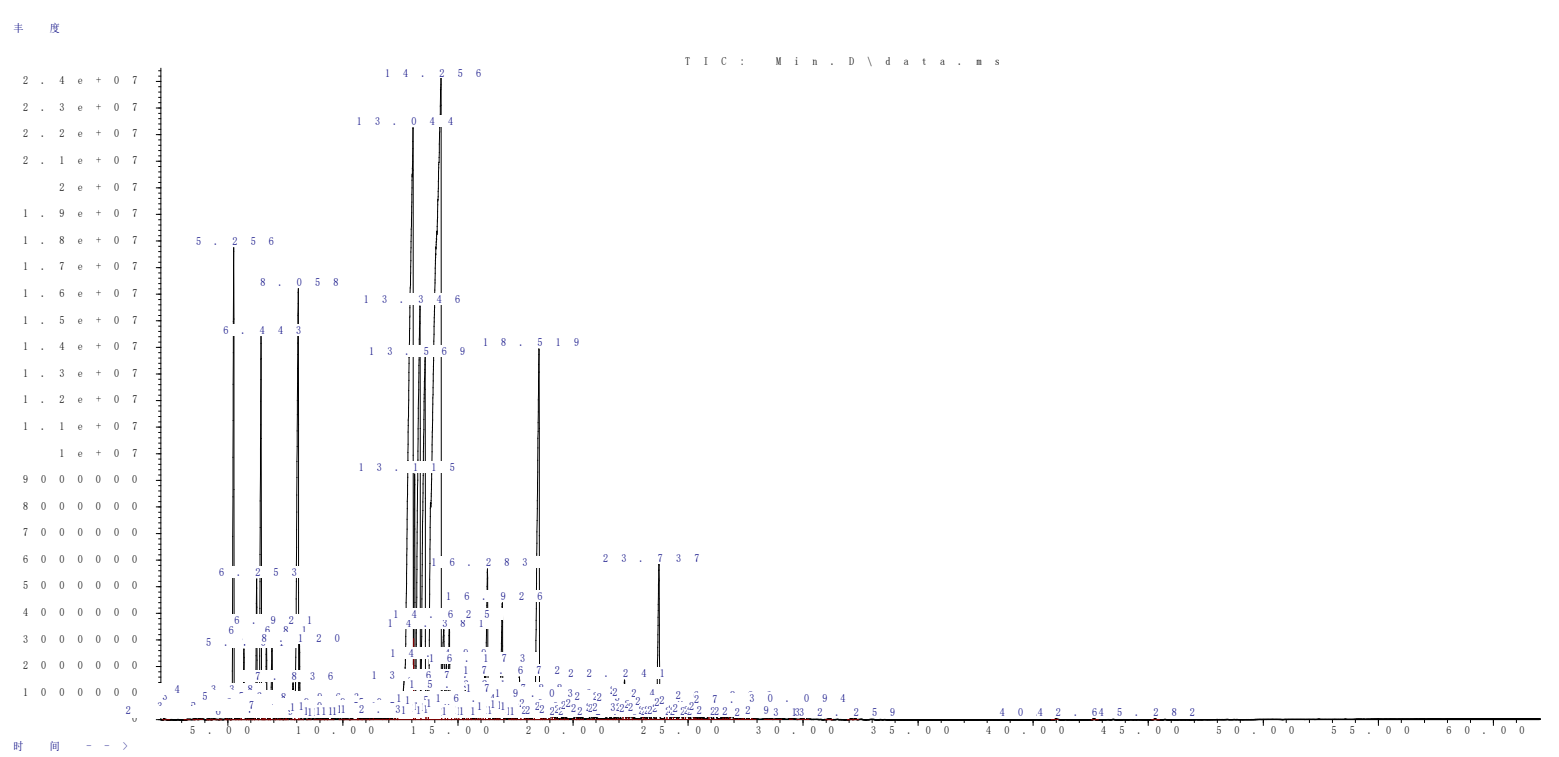

Figure 5. Mint essential oil compounds

Previous studies found menthol 85.89\%, menthone 2.99\% (Lopez-Reyes et al., 2010); Pino et al. (1999) found the major constituents as menthol (51.68\%), menthone (26.08\%) and menthyl acetate (10.55\%) (Pino et al., 
1996).

\subsection{Essential Oils on Fungal Growth Inhibition}

The Minimum Inhibitory Concentrations MICs were determined as the lowest concentration of essential oil inhibiting the visible growth of each organism on the Potato Dextrose Agar PDA plate, Table 1. The MIC was estimated at one fold the concentration $>80 \%$ of inhibition (CLSI, 2012; Carson et al., 1995).

Table 1. The minimum inhibitory concentration of EOs on fungal growth

\begin{tabular}{lll}
\hline Essential oil & Scientific name & $\mathrm{MIC}_{>80 \%}(\mu \mathrm{l} / \mathrm{ml})$ \\
\hline Cinnamon & Cinnamomum verum & $\leq 0.1$ \\
Basil & Ocimum basilicum & $0.5-1$ \\
Citronella & Cymbopogon nardus & $5-10$ \\
Mint & Mentha arvensis & $10-20$ \\
Eucalyptus & Eucalyptus globules & $\gg 10$ \\
\hline
\end{tabular}

Cinnamon is more effective for fungal growth inhibition at the concentration less than $0.1 \mu 1 / \mathrm{ml}$ followed by Basil at $0.5 \mu \mathrm{l} / \mathrm{ml}$ and Citronella $5 \mu \mathrm{l} / \mathrm{ml}$. Mint showed fungal inhibition growth at $10 \mu \mathrm{l} / \mathrm{ml}$, the limit concentration set for the study and Eucalyptus didn't inhibit the fungal growth, it required higher concentration than $10 \mu \mathrm{l} / \mathrm{ml}$.

In Figure 6 the concentration of EOs from Cymbopogon were plotted in accordance with the diameter of the colonies measured after 7 days of incubation. As the concentration increased the diameter of the colony decreased and $3.8 \mathrm{~mm}$ was measured for the concentration of $5 \mu \mathrm{l} / \mathrm{ml}$. The control sample had $80 \mathrm{~mm}$ of diameter leading to a MIC at $95.2 \%(((80-3.8) / 80) * 100)$ according to the formula above (Davari and Ezazi, 2017; Li et al., 2016).

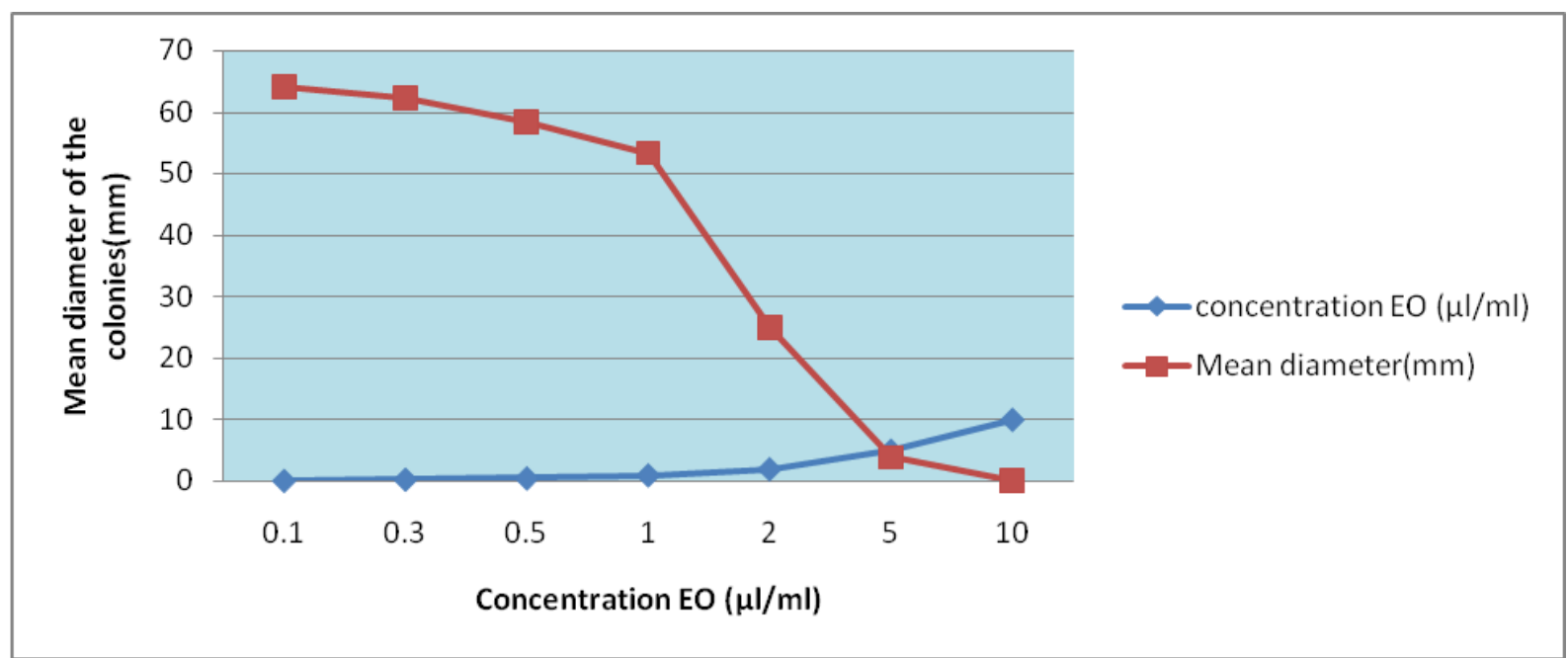

Figure 6. Fungal inhibition per concentration of Cymbopogon nardus

The inhibition was apparent in Figure 7 from the concentration of $30 \mu 1 / 10 \mathrm{ml}$ of medium up to the MIC of $50 \mu \mathrm{l} / 10 \mathrm{ml}$ or $5 \mu \mathrm{l} / \mathrm{ml}$, and there was no visible growth at the concentration of $100 \mu \mathrm{l} / 10 \mathrm{ml}(10 \mu \mathrm{l} / \mathrm{ml})$. This may be due to the damage of cell wall of the fungal by the essential oil leading to the cytoplasm retraction in the hyphae and the death of mycelium (Sharma and Tripathi, 2008), or mitochondrial dysfunction (Bakkali et al., 2008). 


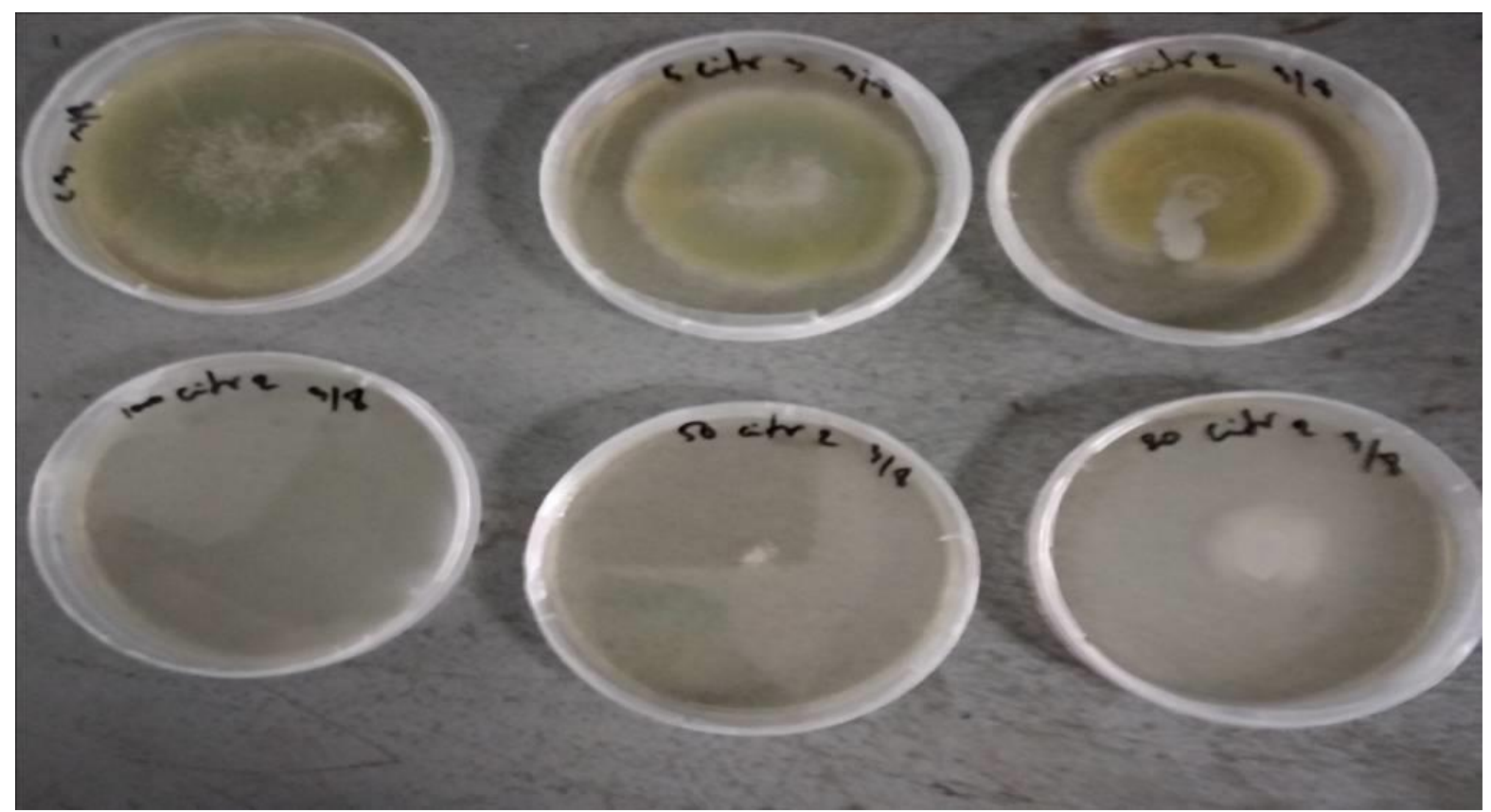

Figure 7.Cymbopogon nardus inhibiting fungal vs control (plate 1)

The Table 2 shows the percentages of fungal growth inhibition per concentration and per EOs namely Cinnamon, Basil, Cymbopogon, Mint and Eucalyptus.

Table 2 . The minimum inhibitory $\%$ of fungal growth per concentration

\begin{tabular}{lllllllll}
\hline Essential oils & Scientific name & \multicolumn{8}{l}{ concentrations $(\mu 1 / \mathrm{ml}) / \%$ inhibition } \\
\hline & & 10 & 5 & 2 & 1 & 0.5 & 0.3 & 0.1 \\
\hline Cinnamon & Cinnamomum verum & 100 & 100 & 100 & 100 & 100 & 100 & $100^{*}$ \\
Basil & Ocimum basilicum & 100 & 100 & 100 & 100 & $86.9^{*}$ & 74.8 & 41.3 \\
Citronella & Cymbopogon nardus & 100 & $95.2^{*}$ & 68.8 & 33.3 & 27.1 & 22.1 & 19.8 \\
Mint & Mentha arvensis & $84.0^{*}$ & 32.3 & 20.8 & 14.6 & 12.9 & 10.8 & 10.6 \\
Eucalyptus & Eucalyptus globulus & 29.4 & 23.1 & 18.8 & 17.3 & 16.3 & 12.7 & 12.1 \\
\hline
\end{tabular}

$* \% \mathrm{MIC}>80 \%$

Cinnamon, Basil, Cymbopogon and Mint EOs inhibit growth of fungal. Some EOs compounds were more efficient in fungal inhibition. This was consistent with previous studies reporting EOs as natural fumigant and playing a significant role to eliminate storage fungi and increase the shelf life in food (Kohiyama et al., 2015; Prakash et al., 2012; Prakash et al., 2015). A study done by Tian et al. (2012) showed that cinnamon is a powerful inhibitor of spore germination and synthesis of Aflatoxins by A. flavus (Tian et al., 2012). The Clinical and Laboratory Standards Institute (CLSI) estimated that an antimicrobial agent as a compound, which can inhibit bacterial and fungal growth at $4 \mu \mathrm{l} / \mathrm{ml}$ to be effective (CLSI, 2012). Thus, Cinnamon, Basil and Citronella can be recommended as preservatives. Eucalyptus was less effective, with only $29.4 \%$ inhibition at the highest concentration studied of $10 \mu \mathrm{l} / \mathrm{ml}$. This has been reported in previous study done by Davari and Ezazi (2017) where 1-8 cineole, the main compound of eucalyptus essential oil was not effective for fungal growth inhibition (Davari and Ezazi, 2017).

\subsection{Sensory Test of Soymilk Flavored with Three Selected Essential Oils}

Cymbopogon nardus, Ocimum basilicum and mentha were randomly selected for sensory evaluation of soymilk as shown in Table 3. As indicated in the form used for sensory analysis from 6 to 9 score were observed, which meant that the product is liked (Hashmi, 2007). All the soymilk samples had acceptable aroma, color, clarity, taste and overall acceptability except the control for aroma only. The more preferred was mint with score 8 corresponding to 'Like very much' followed by Cymbopogon with a score of 7 (Like moderately) and Basil with a mean score of 6.70. The difference between flavors was significant for aroma, taste and overall acceptability 
$(\mathrm{P}<0.05)$.

Table 3. Sensory evaluation of soymilk flavored with 3 EOs at 3 drops per liter

\begin{tabular}{llllll}
\hline Essential oils & Aroma & Color & Clarity & Taste & Overall acceptability \\
\hline Cymbopogon & $6.20 \pm 1.61$ & $8.00 \pm 0.94$ & $7.10 \pm 1.28$ & $7.10 \pm 0.99$ & $7.00 \pm 0.81$ \\
Mint & $8.10 \pm 1.28$ & $7.90 \pm 0.87$ & $7.70 \pm 1.25$ & $7.70 \pm 1.05$ & $8.00 \pm 0.66$ \\
Basil & $6.30 \pm 1.63$ & $7.80 \pm 1.13$ & $7.30 \pm 1.49$ & $6.30 \pm 1.41$ & $6.70 \pm 1.25$ \\
Control & $5.80 \pm 1.03$ & $8.00 \pm 0.94$ & $7.70 \pm 1.16$ & $6.10 \pm 1.52$ & $6.20 \pm 1.31$ \\
Significance: & 0.004 & 0.962 & 0.665 & 0.028 & 0.004 \\
\hline
\end{tabular}

For different concentrations tested using Cymbopogon, Table 4 reports the aroma, color, clarity, taste and overall acceptability of soymilk for 0, 1,2,3 drops of EO used to flavor one liter of soymilk.

Table 4. Sensory evaluation of soymilk using 3 concentrations of Cymbopogon nardus

\begin{tabular}{llllll}
\hline $\begin{array}{l}\text { Concentrations (drops) } \\
\text { Cymbopogon }\end{array}$ & Aroma & Color & Clarity & Taste & Overall acceptability \\
\hline 0 & $5.80 \pm 1.31$ & $7.60 \pm 1.26$ & $7.80 \pm 1.03$ & $6.00 \pm 0.94$ & $6.60 \pm 0.96$ \\
1 & $6.50 \pm 0.97$ & $7.70 \pm 1.25$ & $7.80 \pm 1.03$ & $6.80 \pm 0.91$ & $6.90 \pm 0.73$ \\
2 & $6.60 \pm 0.84$ & $7.50 \pm 1.50$ & $7.80 \pm 1.03$ & $6.80 \pm 1.03$ & $7.00 \pm 0.81$ \\
3 & $7.90 \pm 0.73$ & $7.50 \pm 1.65$ & $7.60 \pm 1.17$ & $7.90 \pm 0.87$ & $7.80 \pm 0.91$ \\
Significance: & 0.000 & 0.987 & 0.967 & 0.001 & 0.025 \\
\hline
\end{tabular}

The three concentrations used to flavor soymilk were accepted with a score above 6 on a scale of 1 to 9 except for the control for aroma, which had a mean score of 5.8. This indicates that flavoring soymilk hides the beany odor and increases the organoleptic attributes of soymilk. Three drops of EOs concentrations were liked very much in soymilk flavoring and the difference between concentrations was significant for aroma, taste and overall acceptability $(\mathrm{P}<0.05)$. The essential oils showed the capacity as food preservative (Harich et al., 2018; Hyldgaard et al., 2012) and increased acceptability of soymilk.

\section{Conclusion}

There was significant effect of EOs compounds on fungal growth inhibition and sensory acceptability of soybean milk. Essential oils compounds are good substances for flavoring soymilk to improve organoleptic attributes and also increase the shelf life as they inhibit fungal growth.

Cinnamon and Basil can be promoted for food preservation at lower concentration, while Mint and Citronella should be promoted for food flavoring. The minimum concentration was determined that will serve as baseline for further use in food industry especially in soymilk.

\section{Acknowledgment}

This project was funded by Organization for Women in Science for the Developing World (OWSD) and Swedish International Development Cooperation Agency (SIDA) through the $\mathrm{PhD}$ fellowship at Oil Crops Research Institute of the Chinese Academy of Agricultural Sciences (CAAS), Wuhan, China. The support from Rwanda Agriculture and Animal Resources Development Board and Jomo Kenyatta University of Agriculture and Technology is highly appreciated. We thank deeply others who contributed for the success of the study.

\section{References}

Adams, R. P. (2017). Identification of essential oil components by Gas chromatography/Mass spectrometry, ed. 4.1, Baylor University.

Bakkali, F., Averbeck, S., Averbeck, D., \& Idaomar, M. (2008). Biological effects of essential oils - A review. Food and Chemical Toxicology, 46, 446-475. https://doi.org/10.1016/j.fct.2007.09.106

Carson, C. F., Hammer, K. A., \& Riley, T. V. (1995). Broth micro-dilution method for determining the susceptibility of Escherichia coli and Staphylococcus aureus to the essential oil of Melaleuca alternifolia (tea tree oil). Microbios, 82, 181-185.

Chamorro, E., Zambon, N. S., Morales, G. W., Sequeira, F. A., \& Velasco, A. G. (2012). Study of the Chemical Composition of Essential Oils by Gas Chromatography. In Salih, B. (Ed.), Gas Chromatography in Plant Science, Wine Technology, Toxicology and Some Specific Applications. InTech. https://doi.org/10.5772/33201 
Clinical and Laboratory Standards Institute (CLSI). (2012). Methods for dilution antimicrobial susceptibility tests for bacteria that grow aerobically; Approved standards, Ninth edition. CLSI document M07-A9, Volume 32, Number 2. Wayne, Pennsylvania, USA.

Davari, M., \& Ezazi, R. (2017). Chemical composition and antifungal activity of the essential oil of Zhumeria majdae, Heracleum persicum and Eucalyptus sp. against some important phytopathogenic fungi. Journal de Mycologie Médicale, 27, 463-468. https://doi.org/10.1016/j.mycmed.2017.06.001

Davles, C. S., Nlelsen, S. S., \& Nielsen, N. C. (1987). Flavor improvement of soybean preparations by genetic removal of lipoxygenase-2. Journal of the American Chemistry's Society, 64(10), 1428. https://doi.org/10.1007/BF02636994

De Martino, L., De Feo, V., \& Nazzaro, F. (2009). Chemical Composition and in Vitro Antimicrobial and Mutagenic Activities of Seven Lamiaceae Essential Oils. Molecules, 14, 4213-4230. https://doi.org/10.3390/molecules 14104213

Fatih, B., Madani, K., Chibane, M., \& Duez, P. (2017). Chemical Composition and Biological Activities of Mentha Species. In El-Shemy, H. A. (Ed.), Aromatic and Medicinal Plants - Back to Nature. InTech. https://doi.org/10.5772/67291

Hammer, K. A., Carson, C. F., \& Riley, T. V. (1999). Antimicrobial activity of essential oils and other plant extracts. Journal of Applied Microbiology, 86, 985-990. https://doi.org/10.1046/j.1365-2672.1999.00780.x

Handa, S. S., Khanuja, S. P., Longo, G., \& Rakesh, D. D. (2008). Extraction Technologies for Medicinal and Aromatic Plants. International centre for science and high technology, Triste.

Harich, M., Maherani, B., Salmieri, S., \& Lacroix, M. (2018). Evaluation of antibacterial activity of two natural bio-preservatives formulations on freshness and sensory quality of ready to eat (RTE) foods. Food Control, 85, 29-41. https://doi.org/10.1016/j.foodcont.2017.09.018

Hashmi, I. (2007). Sensory evaluation techniques, 18th Annual IAOM Conference (MEA District) Muscat-Oman. Retrieved from www.iaom-mea.com/EduMat/.../Tech10-AGF-IAOM-Muscat-07.pdf

Hideo, C., Naofumi, T., \& Ryuzo, S. (1979). Enzymatic Improvement of Food Flavor II. Removal of Beany Flavor from Soybean Products by Aldehyde Dehydrogenase, Agricultural and Biological Chemistry.

Hosken, B. (1999). Advances in soybean processing and utilization. University of Newcastle, method reviewed by Lui, KeShun. Soybeans: Chemistry, Technology and Utilisation, Aspen Pub Inc. Maryland.

Hyldgaard, M., Mygind, T., \& Meyer, R. L. (2012). Essential oils in food preservation: mode of action, synergies, and interactions with food matrix components. Frontiers in Microbiology, 3(12), 1-14. https://doi.org/10.3389/fmicb.2012.00012

Jayaprakasha, G. K., Rao, L. J., \& Sakariah, K. K. (2002). Chemical composition of volatile oil from Cinnamomum zeylanicum buds, Zeitschrift fur Naturforschung C. Journal of Biosciences, 57(11-12), 990-993. https://doi.org/10.1515/znc-2002-11-1206

Kale, R. V., Pandhare, G. R., Satwase, A. N., \& Goswami, D. (2012). Effect of Different Concentration of Orange Juice on Quality Characteristics of Soya Milk Blended Beverage. Journal of Food Processing\&Technology, 3, 140.

Kinney, A. J. (2003). Engineering Soybeans for Food and Health, AgBioForum, 6(1\&2), 18-22. Retrieved from http//www.agbioforum.org. Consulted on 15/03/2015

Kohiyama, C. Y., Yamamoto, R. M. M., Mossini, S. A. G., Bando, E., Bomfim, N. D. S., ... Machinski, M. (2015). Antifungal properties and inhibitory effects upon aflatoxin production of Thymus vulgaris L. by Aspergillus flavus Link. Food Chemistry, 173, 1006-1010. https://doi.org/10.1016/j.foodchem.2014.10.135

Koul, V. K., Gandotra, B. M., Koul, S., Ghosh, S., Tikoo, C. L., \& Gupta, A. K. (2004). Steam distillation of lemongrass (Cymbopogon spp.). Indian Journal of chemical technology, 11, 135-139. https://doi.org/10.1016/j.cageo.2003.07.001

Koutsos, T. V., Chatzopoulou, P. S., \& Katsiotis, S. T. (2009). Effects of individual selection on agronomical and morphological traits and essential oil of a "Greek basil" population. Euphytica, 170, 365-370. https://doi.org/10.1007/s10681-009-0012-7

Laswai, H. S., Thonya, N., Yesaya, D., Silayo, V. C. K., Kulwa, K., Mpagalile, J. J., \& Ballegu, W. R. W. (2009). Use of locally available flavouring materials in suppressing the beany taste in soymilk. African Journal of 
Food Agriculture Nutrition and Development, 9(7), 1548-1560. https://doi.org/10.4314/ajfand.v9i7.47684

Li, Y., Kong, W., Li, M., Liu, H., Zhao, X., Yang, S., \& Yang, M. (2016). Litsea cubeba essential oil as the potential natural fumigant: Inhibition of Aspergillus flavus and AFB1 production in licorice. Industrial Crops and Products, 80, 186-193. https://doi.org/10.1016/j.indcrop.2015.11.008

Lopez-Reyes, J. G., Spadaro, D., Gullino, M. L., \& Garibaldi, A. (2010). Efficacy of plant essential oils on postharvest control of rot caused by fungi on four cultivars of apples in vivo. Flavour and Fragrance Journal, 25, 171-177. https://doi.org/10.1002/ffj.1989

Millet, F. (2015). Huile essentielle Lemongrass, Le grand guide des huiles essentielles. Les Dossiers d'aromateurapie. Retrieved from www.revelessence.com/huile/lemongrass

Moghaddam, M., Farhadi, N., \& Ranjbar, M. (2017). Variability in essential oil content and composition of Ocimum ciliatum accessions from Iran: evidence for three chemotypes, International Journal of Food Properties, 20, 1489-1500. https://doi.org/10.1080/10942912.2017.1352599

Moosavi-Nasab, M., Jamalian, J., Heshmati, H., \& Haghighi-Manesh, S. (2018).The inhibitory potential of Zataria multiflora and Syzygium aromaticum essential oil on growth and aflatoxin production by Aspergillus flavus in culture media and Iranian white cheese. Food Sci Nutr., 6, 318-324. https://doi.org/10.1002/fsn3.557

Muráriková, A., Ťažký, A., Neugebauerová, J., Planková, A., Jampílek, J., Mučaji, P., \& Mikuš, P. (2017). Characterization of Essential Oil Composition in Different Basil Species and Pot Cultures by a GC-MS Method. Molecules, 22, 1221. https://doi.org/10.3390/molecules22071221

Nazzaro, F., Fratianni, F., De Martino, L., Coppola, R., \& De Feo, V. (2013). Effects of essential oils on pathogenic bacteria. Pharmaceuticals, 6, 1451-1474. https://doi.org/10.3390/ph6121451

Niyibituronsa, M., Onyango, A. N., Gaidashova, S., Imathiu, S., Uwizerwa, M., ... Harvey, J. (2019). The effect of different processing methods on nutrient and isoflavone content of soymilk obtained from six varieties of soybean grown in Rwanda. Food Science \& Nutrition, 7, 457-464. https://doi.org/10.1002/fsn3.812

Nyagaya, M. (2008). Améliorer la santé à travers le soja: un guide de formation de base. CIALCA training guide. CIAT Afrique, 1-43.

Özcan, M., \& Chalchat, J.-C. (2011). Essential oil composition of Ocimum basilicum L. and Ocimum minimum L. in Turkey. Czech Journal of Food Sciences, 20, 223-228. https://doi.org/10.17221/3536-CJFS

Pino, J. A., Aristides Rosado, A., \& Fuentes, V. (1996). Chemical Composition of the Essential Oil of Mentha arvensis L. var. piperascens Malinv. from Cuba, Journal of Essential Oil Research, 8(6), 685-686. https://doi.org/10.1080/10412905.1996.9701043

Poonkodi, K. (2016). Chemical composition of essential oil of ocimum basilicumL. (Basil) and its biological activities-an overview. Journal of Critical Reviews, 3(3), 56-62.

Prakash, B., Kedia, A., Mishra, P. K., \& Dubey, N. K. (2015). Plant essential oils as food preservatives to control moulds, mycotoxin contamination and oxidative deterioration of agri-food commodities - Potentials and challenges. Food Control, 47, 381-391. https://doi.org/10.1016/j.foodcont.2014.07.023

Prakash, B., Singh, P., Kedia, A., \& Dubey, N. K. (2012). Assessment of some essential oils as food preservatives based on antifungal, antiaflatoxin, antioxidant activities and in vivo efficacy in food system. Food Research International, 49(1), 201-208. https://doi.org/10.1016/j.foodres.2012.08.020

Ranitha, M., Abdurahman, H. N., Sulaiman, Z. A., Nour, A. H., \& Thana, R. S. (2014). A comparative study of Lemongrass (Cymbopogon citratus) essential oil extracted by Microwave-Assisted Hydrodistillation (MAHD) and conventional Hydrodistillation method. International Journal of Chemical Engineering and Applications, 5(2), 104-108. https://doi.org/10.7763/IJCEA.2014.V5.360

Rao, P. V., \& Gan, S. H. (2014). Cinnamon: A Multifaceted Medicinal Plant. Evidence-Based Complementary and Alternative Medicine, 2014, 1-12. https://doi.org/10.1155/2014/642942

Rassem, H. A., Nour, A. H., \& Yunus, R. M. (2016). Techniques For Extraction of Essential Oils From Plants: A Review. Australian Journal of Basic and Applied Sciences, 10(16), 117-127.

Regnault-Roger, C. (1997). The potential of botanical essential oils for insect pest control. Integrated Pest Management Reviews, 2, 25-34. https://doi.org/10.1023/A:1018472227889

Sharma, N., \& Tripathi, A. (2008). Effects of Citrus sinensis (L.) Osbeck epicarp essential oil on growth and 
morphogenesis of Aspergillus niger (L.) Van Tieghem. Microbiological Research, 163, 337-344. https://doi.org/10.1016/j.micres.2006.06.009

Sustainable Baby Steps (May, 2019). Basil Essential Oil: Uses, Benefits, and Precautions. Retrieved from www.sustainablebabysteps.com/basil-essential-oils.html

Tandon, S. (2008). Distillation Technology for Essential Oils. In Handa et al., 2008. Extraction Technologies for Medicinal and Aromatic Plants. International centre for science and high technology, Triste, chapter, 7 , 115-127.

Tian, J., Huang, B., Luo, X., Zeng, H., Ban, X., He, J., \& Wang, Y. (2012). The control of Aspergillus flavus with Cinnamomum jensenianum Hand.-Mazz essential oil and its potential use as a food preservative. Food Chemistry, 130(3), 520-527. https://doi.org/10.1016/j.foodchem.2011.07.061

Vangalapati, M., Sree Satya, N., Surya Prakash, D., \& Avanigadda, S. (2012). A review on pharmacological activities and clinical effects of cinnamon species. Research Journal of Pharmaceutical,Biological and Chemical Sciences, 3(1), 653-663.

Wany, A., Jha, S., Nigam, V. K., \& Pandey, D. M. (2013). Chemical analysis and therapeutic uses of citronella oil from cymbopogon winterianus: A short review. International Journal of Advanced Research, 1(6), 504-521.

\section{Appendix}

\section{Sensory evaluation of soymilk}

Date:.

Put the sign $\times$ in the case where your age and gender belong

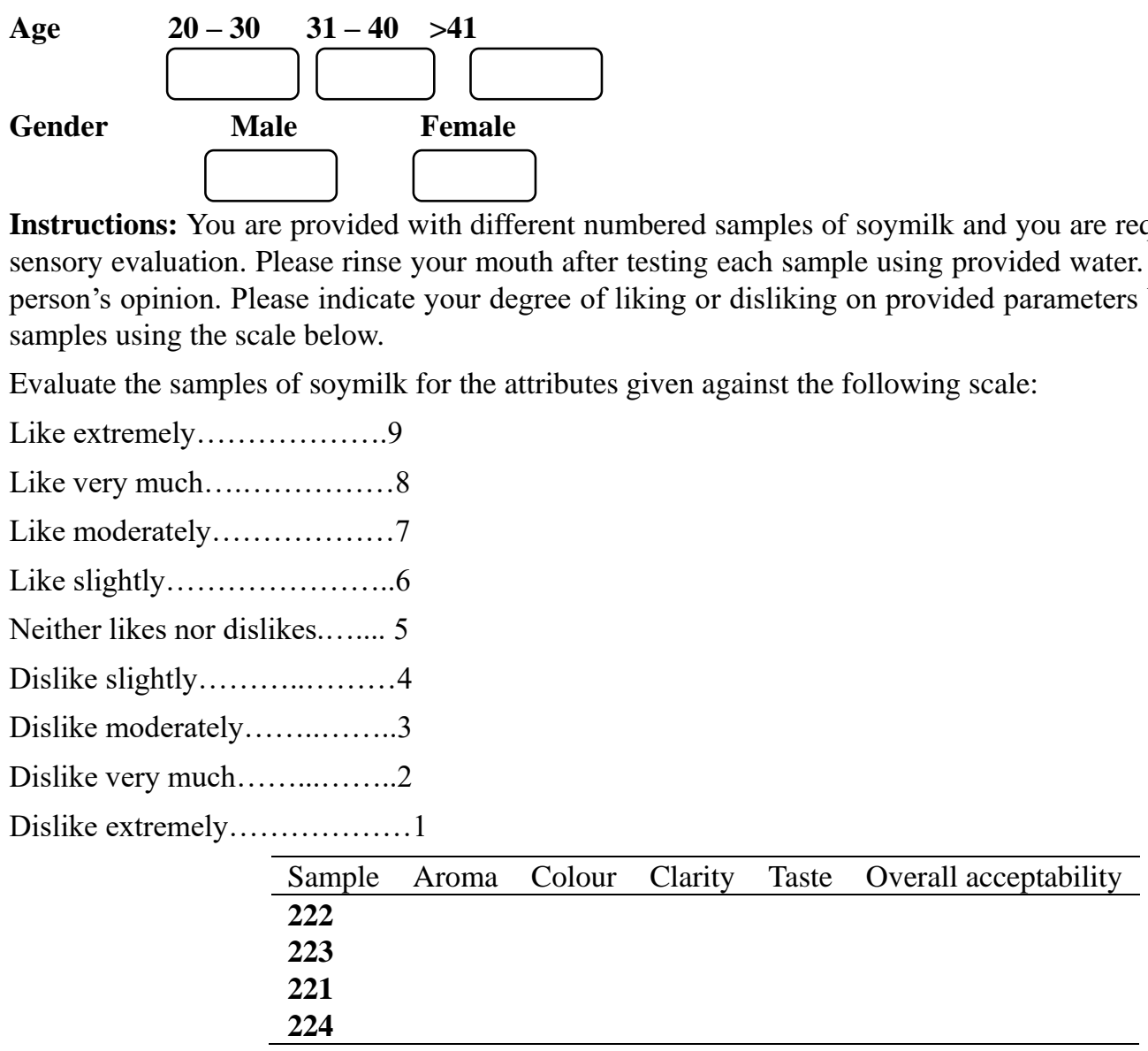

Thank you 


\section{Copyrights}

Copyright for this articleis retained by the author(s), with first publication rights granted to the journal.

This is an open-access article distributed under the terms and conditions of the CreativeCommons Attribution license (http://creativecommons.org/licenses/by/4.0/). 